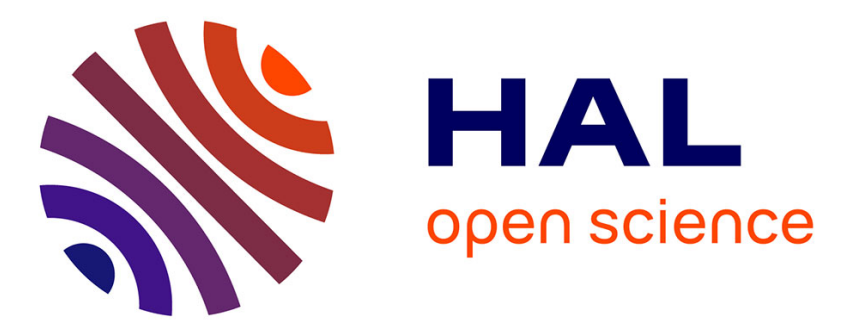

\title{
Nouvelle stratégie pour vectorisation d'ARN dans des cellules de mammifères. Utilisation d'un vecteur peptidique
}

Pierre Vidal, May C Morris, Laurent Chaloin, Frédéric Heitz, Gilles Divita

\section{- To cite this version:}

Pierre Vidal, May C Morris, Laurent Chaloin, Frédéric Heitz, Gilles Divita. Nouvelle stratégie pour vectorisation d'ARN dans des cellules de mammifères. Utilisation d'un vecteur peptidique. Comptes Rendus de l'Académie des Sciences - Series III - Sciences de la Vie, 1997, 320 (4), pp.279-287. 10.1016/S0764-4469(97)82769-2 . hal-03149823

\section{HAL Id: hal-03149823 \\ https://hal.umontpellier.fr/hal-03149823}

Submitted on 10 Mar 2021

HAL is a multi-disciplinary open access archive for the deposit and dissemination of scientific research documents, whether they are published or not. The documents may come from teaching and research institutions in France or abroad, or from public or private research centers.
L'archive ouverte pluridisciplinaire HAL, est destinée au dépôt et à la diffusion de documents scientifiques de niveau recherche, publiés ou non, émanant des établissements d'enseignement et de recherche français ou étrangers, des laboratoires publics ou privés.

\section{(c)(1)}

Distributed under a Creative Commons Attribution| 4.0 International License 


\title{
Nouvelle stratégie pour vectorisation d'ARN dans des cellules de mammifères. Utilisation d'un vecteur peptidique
}

\author{
Efficient RNA delivery into non-transformed mammalian cells \\ by using a peptide vector
}

\author{
Pierre Vidal*, May Catherine Morris*, Laurent Chaloin, Frédéric Heitz, Gilles Divita** \\ Centre de recherches de biochimie macromoléculaire. URS 155 CNRS, BP 5051, 1919, route de Mende, 34033 Montpellier cedex 1, France
}

\begin{abstract}
RÉSUMÉ
Le problème majeur rencontré lors du transfert de gène et/ou d'oligonucléotides dans les cellules de mammiferes tient à la faible perméabilité des cellules aux acides nucléiques. Dans ce travail nous avons développé une nouvelle stratégie pour la vectorisation d'acides nucléiques, basée sur l'utilisation d'un peptide court (MPG) associant les propriétés d'une séquence de fusion dérivant de la protéine gp 41 de VIH avec celle d'une séquence de signalisation nucléaire dérivant de l'antigène $\mathrm{T}$ de SV40. Ce vecteur peptidique diffuse rapidement dans les fibroblastes humain (HS-68) en culture, avec une localisation majoritairement nucléaire en moins de trois minutes. MPG présente une forte affinité pour l'ARNm codant pour la sous-unité de $66 \mathrm{kDa}$ de la transcriptase inverse du VIH $(\mathrm{Kd}=100 \mathrm{nM})$. La formation du complexe peptide/acide nucléique se fait majoritairement par des interactions électrostatiques impliquant les résidus basiques du peptide et les charges négatives des groupements phosphates de l'ARN. Ce vecteur permet a lui seul de transférer rapidement $(1 \mathrm{~h})$ et avec un rendement supérieur à $80 \% \mathrm{cct} \Lambda \mathrm{RNm}$ dans des fibroblastes cn culture. De plus, MPG n'affecte pas la traduction de l'ARNm transféré et présente l'avantage d'être non cytotoxique aux concentrations utilisées pour le transfert d'ARN. Ce nouveau vecteur constitue un excellent outil pour développement du transfert de gênes.
\end{abstract}

Mots clés : vectorisation, transfert de gêne, ARN, VIH, peptide vecteurs

\begin{abstract}
A major barrier for gene delivery is the low permeability of nucleic acids to cellular membranes. The development of antisenses and gene therapy has focused mainly on improving methods of oligonucleotide or gene delivery to the cell. In this report we described a new strategy for RNA cell delivery, based on a short single peptide. This peptide vector is derived from both the fusion domain of the gp 41 protein of $H I V$ and the nuclear localization sequence of the SV4O large T antigen. This peptide vector localizes rapidly to the cytoplasm then to the nucleus of human fibroblasts (HS-68) within a few minutes and exhibits a bigh affinity for a single-stranded mRNA encoding the $p 66$ subunit of the HIV-1 reverse transcriptase (in a $100 \mathrm{nM}$ range). The peptide/RNA complex formation involves mainly electrostatic interactions between the basic residues of the peptide and the charges on the phosphate group of the
\end{abstract}

Note présentée par Claude Hélène

Note remise le 13 décembre 1996, acceptée après révision le 24 mars 1997

${ }^{*}$ Ces deux auteurs ont contribué à part égale à ce travail

${ }^{* *}$ Correspondance et tirés à part 
RNA. In the presence of the peptide-vector fluorescently-labelled $m R N A$ is delivered into the cytoplasm of mammalian cells (HS68 human fibroblasts) in less than $1 \mathrm{~h}$ with a relatively high efficiency (80\%). This new concept based on a peptide-derived vector offers several advantages compared to other compounds commonly used in gene delivery. This vector is highly soluble and exhibits no cytotoxicity at the concentrations used for optimal gene delivery. This result clearly supports the fact that this peptide vector is a powerful tool and that it can be used widely, as much for laboratory research as for new applications and development in gene andlor antisense therapy.

Key words: gene delivery. HIV, RNA, peptide vector

\section{Abridged version (see p. 286)}

\section{Introduction}

Le transfert d'oligonucléotides ou de gènes dans les cellules constitue un moyen puissant d'une part pour comprendre la fonction ainsi que la régulation de l'expression des gènes et d'autre part, pour accéder à des thérapies géniques $[1,2]$. Cependant son utilisation reste encore restreinte du fait de plusieurs exigences : i) le passage à travers les barrières membranaires, ii) la présence de l'oligonucléotide ou de l'acide nucléique en concentration suffisante pour son interaction avec sa cible cellulaire, iii) le maintien de l'intégrité et de la stabilité de l'acide nucléique transféré dans les cellules et iv) la sélectivité vis-à-vis d'une cible ou du compartiment cellulaire [1-3]. À ce jour, bien qu'un large éventail de méthodes ait été proposé pour faciliter la pénétration d'acides nucléiques dans les cellules de mammifères, les vecteurs viraux, du fait de leur efficacité, restent encore les principaux outils utilisés pour le transfert de gènes in vivo et en thérapie génique [3]. Ils présentent cependant un certains nombre d'inconvénients tels que des risques de pathogénicité ou de complications immunologiques. Dans le but de palier ces problèmes, un important effort est consenti pour développer des technologies non virales. Deux types d'approches ont été principalement proposées : i) les lipides cationiques tel que le DOGS (dioctadecylamido glycylspermine) [4] ou la Lipofectamine ${ }^{\top N}$ et la Cytofectine $^{\mathrm{TM}}[5-7]$, ii) les polymères formant des complexes avec le DNA comme les poly-L-lysine [8, 9], protamine et polyethylenimine qui présentent un fort potentiel de charge cationiques $[10,11]$. Ces méthodes présentent plusieurs avantages par rapport aux vecteurs viraux : elles sont peu contraignantes en ce qui concerne la taille de I'acide nucléique, et les vecteurs utilisés peuvent être synthétisés en grande quantité et sont simples d'utilisation. De plus les risques de pathogénicité et de complications immunologiques sont fortement réduits. Toutefois, elles restent moins efficaces que les vectcurs viraux et leur uti lisation présente des limitations : i) ces agents sont sensibles à la présence de sérum, ii) les rendements de transfection sont variables en fonction des lignées cellulaires utilisées et iii) ils présentent dans certains cas une cytotoxycité importante [7].
Dans ce travail nous proposons une nouvelle approche pour le transfert de gène dans les cellules de mammifères en culture. Cette stratégie est basée sur l'utilisation d'un peptide court associant les propriétés d'un peptide de fusion à celle d'un signal de localisation nucléaire. Gottschalk et al. ont démontré que l'association d'un peptide comportant plusieurs "clusters " de lysines, avec des peptides favorisant le relargage au niveau des endosomes permettait le transfert d'ADN dans la cellule [13]. Le vecteur peptidique que nous avons développé se complexe avec les acides nucléiques par l'intermédiaires d'interactions électrostatiques. Il permet à lui seul de transférer, avec un fort rendement des ARNm dans des fibroblastes humains en culture qui sont ensuite rapidement traduits dans la cellule. Ce vecteur a été développé dans le cadre précis du développement d'inhibiteurs de la transcriptase inverse du VIH [14], en transférant un ARNm codant pour une sous-unité de cette enzyme. Parallèlement, la traduction des ARNs transfectés a été suivie à l'aide d'un gène raporteur codant pour la luciferase de Renilla reniformis.

\section{Matériel et méthodes}

\section{Synthèse et purification des peptides}

Le peptide (MPG) de séquence " G-A-L-F-L-G-F-L-G-A-AG-S-T-M-G-A-W-S-A-P-K-S-K-R-K-V-Cya " a été synthétisé en phase solide sur un synthétiseur 9050 Pepsynthetizer Milligen (Millipore, Royaume-Uni) avec une résine Expansin fonctionnalisée par un groupement aminoethyl dithio acide 2 -isobutyrique compatible avec la stratégie Fmoc [15]. Après coupure du peptide de la résine, ce groupement donne naissance à une fonction cystéamide (Cya) portée par l'extrémité C-terminale. Le peptide a été purifié par HPLC semi-préparative, il est élué avec $35 \%$ d'acétonitrile dans $1 \%$ de TFA, avec un débit de $5 \mathrm{~mL} / \mathrm{min}$. Le peptide a été caractérisé par spectrométrie de masse en électrospray et analyse d'acides aminés. Afin de suivre le devenir cellulaire du peptide MPG libre, nous avons couplé covalemment au peptide en position C-terminale un colorant, le jaune Lucifer, par l'intermédiaire du groupement réactif cystéamide comme précédemment décrit [16]. 


\section{Préparation des polyribonucléotides}

Les ARNs utilisés pour les expériences d'interaction et de transfection cellulaire codent respectivement pour la sous-unité catalytique (p66) de la transcriptase inverse du virus d'immunodéficience humain (VIH) [17] et pour la luciferase de Renilla reniformis [18] dérivant du vecteur d'expression eucaryote pRL-SV40 [19]. Les ARNm correspondant (1,4 et 1,6 Kbases, respectivement) sont synthétisés par expression sous contrôle du promoteur de la polymérase $\mathrm{T7}$. Ils sont purifiés selon les protocoles standard, par précipitation au $\mathrm{LiCl}$ suivie d'une précipitation à l'éthanol [20]. Le dérivé fluorescent de I'ARNm codant pour la sous-unité p66 de la reverse transcriptase est préparé selon la même méthode à partir de ribonucléotides fluorescents [21].

\section{Spectroscopie de fluorescence}

Les mesures de fluorescence ont été effectuées sur un spectofluorimètre SPEX II (Jobin Yvon) à $25^{\circ} \mathrm{C}$ dans un tampon contenant $17 \mathrm{mM} \mathrm{KH} \mathrm{PO}_{4}, 5 \mathrm{mM} \mathrm{Na}{ }_{2} \mathrm{HPO}_{4}$, $150 \mathrm{mM} \mathrm{NaCl}, \mathrm{pH} 7,5$. Afin de limiter les effets de filtre associés à la présence d'acides nucléiques, la fluorescence du tryptophane de MPG est excitée à $295 \mathrm{~nm}$ et le spectre d'émission est enregistré entre 310 et $410 \mathrm{~nm}$. Les spectres d'émissions obtenus sont corrigés en fonction des paramètres du fluorimètre et du facteur de dilution [22]. Les titrations sont effectuées à partir d'une concentration fixe de MPG $\left(510^{-6} \mathrm{M}\right)$ non marqué avec le jaune Lucifer et des concentrations croissantes d'ARNm 10 à $4 \mathrm{nM}$ ). L'analyse des courbes de titration est effectuée à l'aide d'équation quadratique avec le programme Grafit (Erithacus Software Ltd) comme précédemment définie [23].

\section{Cultures et localisation cellulaires}

Les fibroblastes humains HS 68 sont cultivés dans le milieu DMEM (Dulbecco's modifiée Eagle's medium) avec $10 \%$ de sérum de veau foetal, pénicilline/streptomycine et glutamine à $37^{\circ} \mathrm{C}$ puis enscmencées sur des lames couvre-objet en verre et incubées jusqu'à $75 \%$ de confluence. Pour les expériences de localisation cellulaire, le peptide MPG marqué $\left(0,510^{-6} \mathrm{M}\right)$ en position C-terminale avec le jaune lucifer est incubé directement sur les cellules pendant 1 à 3 min à $37^{\circ} \mathrm{C}$. Pour les expériences de vectorisation d'ARN, les complexes MPG/ARNm fluorescents sont préalablement formés dans du tampon PBS en utilisant des concentrations respectives de $1,10^{-10} \mathrm{M}$ (ARN) et $0,510^{-5} \mathrm{M}$ (MPG). Les fibroblastes sont ensuite incubés de 30 min à $2 h$, en présence de ces complexes MPG/ARNm fluorescent ou non, dans du milieu de culture contenant $10 \%$ de sérum. Dans les deux cas, les lames couvre-objet sont ensuite rincées et les cellules fixées comme définie précédemment [24]. Les cellules sont observées par microscopie confocale, [25] ou par microscopie de fluorescence [26]. Les expériences de contrôle de la vectorisation d'ARN ont été effectuées en utilisant la méthode de transfection par des lipides catio- niques, Lipofectamine ${ }^{T M}[5,6]$ selon le protocole commercial. La traduction de l'ARN transfecté est suivie par l'expression d'ARN reporteur codant pour la luciférase de Renilla reniformis 118,19$]$. L'ARN correspondant est transfecté en présence de MPG pendant $1 \mathrm{~h}$, les cellules sont ensuite rincées deux fois avec du milieu de culture contenant $10 \%$ de sérum et maintenues dans ce milieu de culture pendant $48 \mathrm{~h}$. Les cellules sont lysées, centrifugées et l'activité luciférase est mesurée $4,6,8$ et $12 \mathrm{~h}$ après la transfection avec MPG, en utilisant le KIT Dual Luciférase [19].

\section{Résultats et discussion}

\section{Conception du peptide vecteur MPG}

Lors de la vectorisation de gènes ou d'oligonucléotides dans les cellules, la difficulté majeure réside dans la faible perméabilité des membranes cellulaires aux acide nucléiques. Afin de contourner cet obstacle, nous avons élaboré un peptide vecteur (MPG), sur la base des critères suivants : ce peptide doit i) comporter une séquence hydrophobe facilitant le franchissement des barrières membranaires, ii) posséder une séquence hydrophile chargée positivement afin de favoriser les interactions électrostatiques avec les oligonucléotides au niveau des groupements phosphates, iii) les deux séquences doivent être séparées par une séquence de liaison augmentant leur flexibilité et dont la présence est indispensable pour induire une localisation intracellulaire du peptide. En conséquence, nous avons conçu un peptide MPG de 27 résidus « G-A-L-F-L-G-F-L-G-A-A-G-S-T-M-G-A-W-SQ-P-K-S-K-R-K-V-Cya ", qui comporte deux domaines distincts : i) un domaine hydrophobe en position $\mathrm{N}$-terminale "G-A-L-F-L-G-F-L-G-A-A-G-S-T-M-G-A " dérivant de la séquence de fusion de la protéine membranaire gp41 du VIH $[26,27]$, qui est indispensable à la fusion entre l'enveloppe du virus et la membrane des cellules lymphocytaires et ii) un domaine hydrophile en position C-terminale "P-K-S-K-R-K-V ", dérivant du peptide signal responsable de l'adressage nucléaire du virus SV40 [28, 29l. Ces deux domaines sont séparés par une courte séquence "W-S-Q ", comportant un résidu tryptophane qui est une excellente sonde fluorescente intrinsèque. L'extrémité $\mathrm{N}$-terminale du peptide a été acétylée afin d'augmenter son profil d'hydrophobicité et donc de faciliter sa pénétration dans le milieu lipidique membranaire. La synthèse du peptide et l'acétylation de l'extrémité $\mathrm{N}$ terminale sont effectuées directement sur la résine Expansin. Le peptide est ensuite purifié par HPLC semi-préparative en phase inverse avec un rendement de $70 \%$ et identifié par spectroscopie de masse en electrospray par une valeur de masse mesurée de $\mathrm{MH}^{+}$avec $\mathrm{m} / \mathrm{z}-2864$ (théorique : 2 867). Le peptide comporte un groupement réactif (fonction $\mathrm{S}-\mathrm{H}$ du groupement cystéamide) permettant ainsi le greffage post-synthèse d'un chromophore; le 
jaune Lucifer, qui servira de marqueur pour visualiser le peptide libre dans les cellules.

\section{Localisation cellulaire du peptide vecteur MPG}

Le routage et la localisation cellulaire du peptide vecteur MPG ont été suivis sur des fibroblastes humain (HS 68) en utilisant un peptide marqué covalemment à l'extrémité C-terminale avec le jaune Lucifer (figure 1). La forme libre du jaune Lucifer est rapidement inlemalisée et présente une localisation majoritairement périnucléaire (figure 1 A/B). Au contrairc, lorsque le chromophore est fixé sur le peptide MPG, il diffuse rapidement dans la cellule et présente un localisation majoritairement nucléaire (figure $1 \mathrm{E} / \mathrm{F}$ ). L'étude de la cinétique de pénétration de MPG démontre que le vecteur diffuse rapidement à travers la membrane plasmique, aprés un temps d'incubation de $1 \mathrm{~min}$, il se retrouve aussi bien dans le noyau que dans la membrane plasmique des cellules (figure $1 \mathrm{C} / \mathrm{D}$ ). En revanche, pour des temps d'incubation plus long (3 $\mathrm{min}$ ), un fort pourcentage du peptide présente une localisation nucléaire (figure 1E/F). Cette diffusion rapide vers le noyau du peptide est une consé- quence directe de la présence du groupement NLS en postion C-terminale.

\section{Étude de la formation des complexes MPG/ARNm par fluorescence intrinsèque}

Le peptide MPG comporte un seul résidue Trp18, qui lui confère une importante fluorescence intrinsèque, avec un maximum d'émission centré à $340 \mathrm{~nm}$ (figure $2 \mathrm{~A}$ ), indiquant que le résidu Trp n'est pas totalement exposé à la phase aqueuse [30] et que le peptide est partiellement structuré dans le tampon utilisé pour les expériences d'association avec I'ARN. Nous avons utilisé cette sonde intrinsèque pour étudier et quantifier les interactions entre MPG et l'ARNm codant pour la sous-unité catalytique de la transcriptase inverse du $\mathrm{VIH}(1,4 \mathrm{~Kb})$. La fixation d'ARNm sur MPG entraîne une atténuation de $23 \%$ de la fluorescence intrinsèque, sans toutefois induire de déplacement du spectre d'émission (figure $2 \mathrm{~A}$ ). Ces résultats démontrent que la fixation d'ARN n'affecte pas directement l'environnement du Trp, mais que l'atténuation de fluorescence serait majoritairement associée à une interaction directe avec l'acide nucléique. Les courbes de titration obtenues (figure 2B) sont identiques pour les
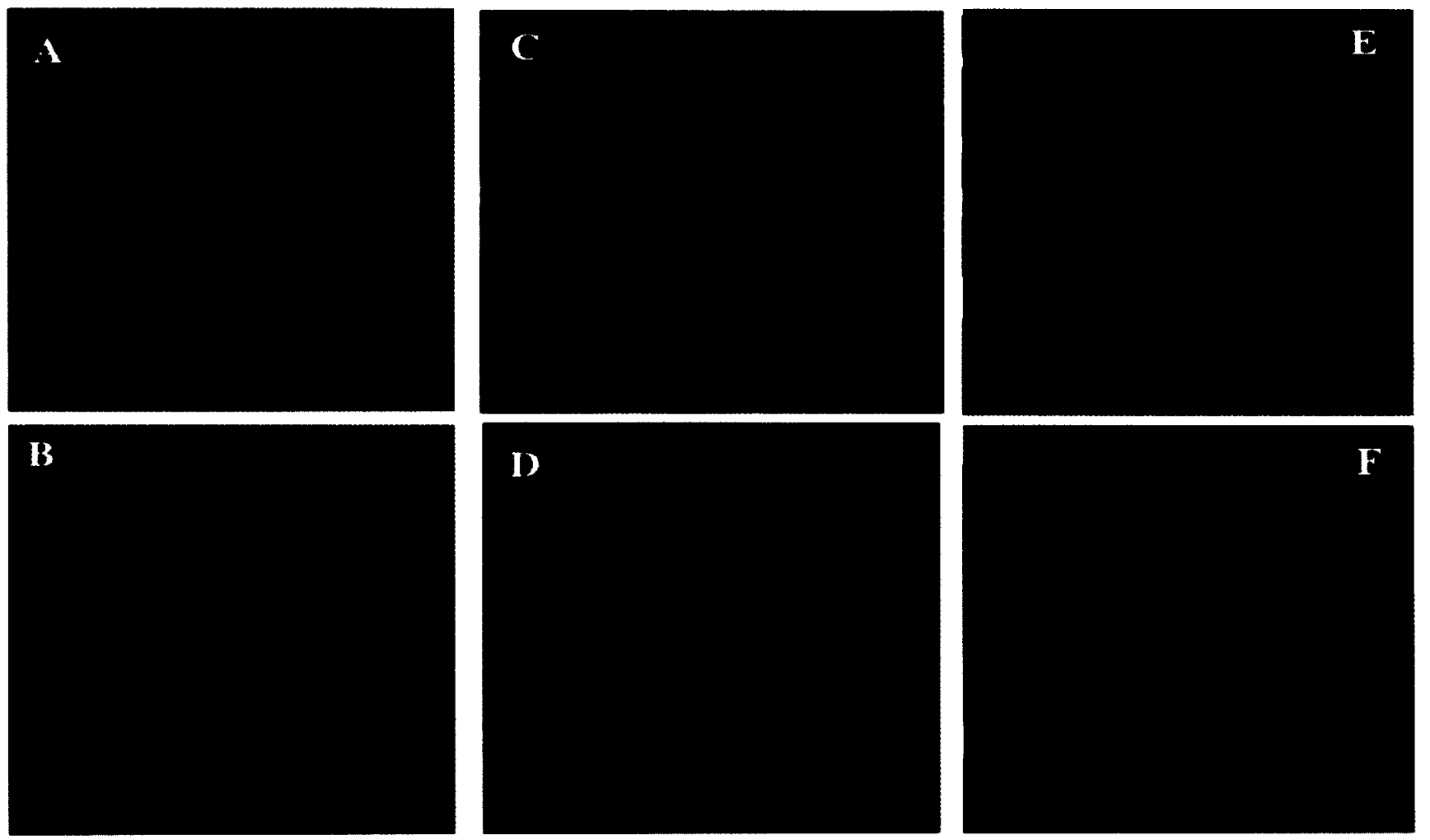

Higure 1. Localisation cellulaire du peptide vecteur MPG.

La localisation cellulaire du peptide vecteur MPG a été effectuée sur des fibroblastes humain (HS-68). Le vecteur MPG comporte une molécule de jaune Lucifer covalemment accrochée en position C-terminale par l'intermédiaire du groupement cystéamide. Les cellules sont observées par microscopie confocale et les noyaux ont été révélés par marquage au Hoechst 33258. A : Localisation cellulaire de la forme libre du jaune Lucifer. $\boldsymbol{C}$ et $\boldsymbol{E}:$ Localisation cellulaire du peptide vecteur MPG fluorescent après respectivement 1 et 3 min d'incubation sur les cellules maintenue dans du milieu de culture avec $10 \%$ de sérum. $\boldsymbol{B}, \boldsymbol{D}, \boldsymbol{F}$ : Contrôle de localisation des noyaux par marquage au Hoechts 33258. 
ARNs non fluorescents et marqués avec la fluorescéine, suggérant que les groupements fluorescents fixés sur I'ARN ne modifie pas son interaction avec MPG. Ces résultats valident l'utilisation d'un tel marquage fluorescent de I'ARN pour sa localisation cellulaire [18]. La saturation de MPG (5 $\left.10^{-6} \mathrm{M}\right)$ est obtenue, pour une concentration d'ARN 4000 fois plus faible, ce qui nous pcrmet d'cstimer un nombre de peptides vecteurs présents par molécule d'ARN de l'ordre de 4000 . Cette valeur est 13 fois supérieure à celle calculée $(\sim 300)$ en tenant compte uniquement du rapport des charges accessibles entre les groupements phosphates de I'ARN et les différents résidus chargés de MPG qui sont au total de 4 (3 Lys et $1 \mathrm{Arg}$ ). En conséquence, la formation du complexe MPG/ARN serait due, d'une part, à des interactions électrostatiques entre MPG et l'acide nucléique qui engendrerait dans un deuxième temps la formation de contacts peptide/peptide. Au contraire, en absence d'ARN, aucune interactions peptide/peptide n'a pu être mise en évidence dans les gammes de concentration de
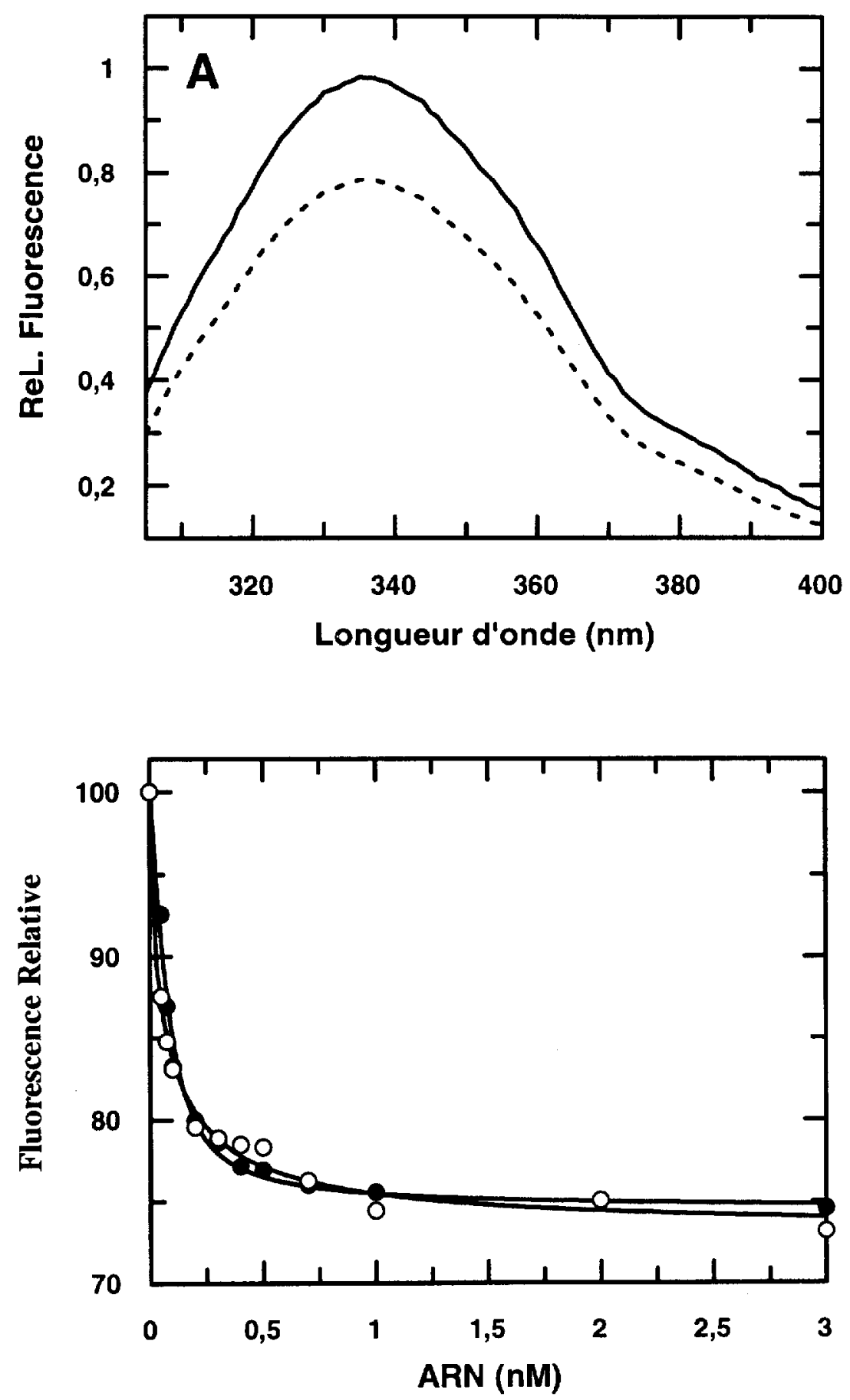

Figure 2. Étude par fluorescence de l'interaction entre MPG et I'ARN fluorescent et non marqué.

La titration de MPG par I'ARN codant pour la sous-unité 066 de la transcriptase inverse de $V I H$ est effectuée à $25^{\circ} \mathrm{C}$ dans un tampon contenant $17 \quad \mathrm{mM} \quad \mathrm{KH}_{2} \mathrm{PO}_{4}, \quad 5 \mathrm{mM}$ $\mathrm{Na}_{2} \mathrm{HPO}_{4}, 150 \mathrm{mM} \mathrm{NaCl}, \mathrm{pH}$ 7. A : Spectres d'émission du peptide MPG $(0.5 \mu M)$ en absence et en présence d'une concentration saturante d'ARNm (4 nM). B : Courbes de litralion de MPG par l'ARNm. Une concentration de MPG (5 $\left.10^{-6} \mathrm{M}\right)$ est titrée par des concentrations croissantes $d^{\prime} A R N(\bullet)$ et d'ARN fluorescent (o). La fluorescence du tryptophane de MPC est excitée à $295 \mathrm{~nm}$ et les spectres d'émission sont intégrés entre 310 et $410 \mathrm{~nm}$. Les différentes mesures sont corrigées et analysées comme décrit dans Matériel et méthodes. 
$10^{-9}$ à $10^{-4} \mathrm{M}$, confirmant que ces interactions peptide/peptide sont bien conséquente de la fixation de I'ARN. Le peptide MPG présente une forte affinité pour I'ARN étudié avec une constante de dissociation apparente de $1,210^{-7} \mathrm{M}$ calculée à partir de l'analyse quadratique des courbes de titration en estimant que 4000 molécules de peptides sont fixés sur une molécule d'ARNm.

\section{Transfert d'ARNm dans des cellules de mammifères par le vecteur MPG}

La potentialité de MPG à transférer des acides nucléiques dans des cellules de mammifères non transformées (fibroblastes humain HS-68) a été étudié en utilisant un dérivé fluorescent de l'ARN codant pour la sous-unité p66 de la transcriptase inverse. Parallèlement, nous avons comparé cette nouvelle stratégie à la méthode classiquement utilisée pour le transfert de gène, les lipides cationiques comme la lipofectamine ${ }^{\mathrm{TM}}[5,6]$. L'ARN fluorescent est transporté dans le cytoplasme par la lipofectamine ${ }^{T M}$. Dans ce cas, un rendement maximal de transfection de $50 \%$ a été obtenue après un minimum de $5 \mathrm{~h}$ de transfection dans du milieu dépourvue de sérum. Lors de la transfection avec le vecteur MPG, I'ARN fluorescent est préalablement associé au peptide MPG dans un rapport de 1/2 000 (ARN/vecteur) dans du tampon PBS. Le complexe MPG/ARN préformé est ajouté directement au milieu de culture des cellules (contenant $10 \%$ de sérum). Comme le démontre la présence de "spots » fluorescents dans les cellules (figure $3 \mathrm{C} / \mathrm{E}$ ), l'ARN-fluorescent est rapidement transporté vers le cytoplasme. L'étude de la cinétique de transfert de l'ARN par MPG montre que pour des temps de transfection inférieurs à 30 min le transfert n'est pas total, une partie de la fluorescence restant membranaire. Au contraire, après $1 \mathrm{~h}, \mathrm{I}$ 'ARN est totalement dans le cytoplasme avec un nombre de cellules transfectées supérieure à $90 \%$ (figure $3 \mathrm{E}$ ). L'absence de fluorescence dans le noyau après des temps courts (< 30 min) qui correspondrait à des fluorophores libérés par dégradation de I'ARN suggère que la présence du vecteur MPG protègc I'ARN contre la dégradation. Au contraire, en absence de MPG, aucune fluorescence n'est détectée dans les cellules confirmant que I'ARN seul est incapable de pénétrer dans les cellules (figure $3 \mathrm{~A}$ ).

\section{Mesure de l'expression des ARNm transfectés par le MPG}

Le peptide vecteur MPG permet un transfert physique d'ARNm dans les cellules en $1 \mathrm{~h}$. Dans cette dernière partie l'expression de I'ARNm transféré par MPG a été étudiée en utilisant un ARNm codant pour la luciferase de Renilla reniformis $[18,19]$ Le complexe MPG/ARN préformé dans un rapport de 1/1000 a été mis au contact de cellules [HS-68) en culture pendant $1 \mathrm{~h}$. Les cellules sont ensuite rincées et incubées dans du mileu de culture contenant $10 \%$ de sérum et l'activité luciférase a été mesurée après $4,6,8,10$ et $12 \mathrm{~h}$ de culture (figure 4 ). L'analyse des résultats révèle une importante expression de I'ARN qui est optimale après seulement $6 \mathrm{~h}$, au lieu de $12 \mathrm{~h}$ dans le cas du contrôle avec la lipofectamine ${ }^{\mathrm{MM}}$. L'activité luciférase normée par rapport à la concentration en protéine est deux fois plus importante dans le cas de transfection aver. MPG, qui est en parfait accord avec les rendements observés par transfert d'ARN fluorescent. Ces résultats confirment que l'ARN tranfecté avec le peptide vecteur MPG est
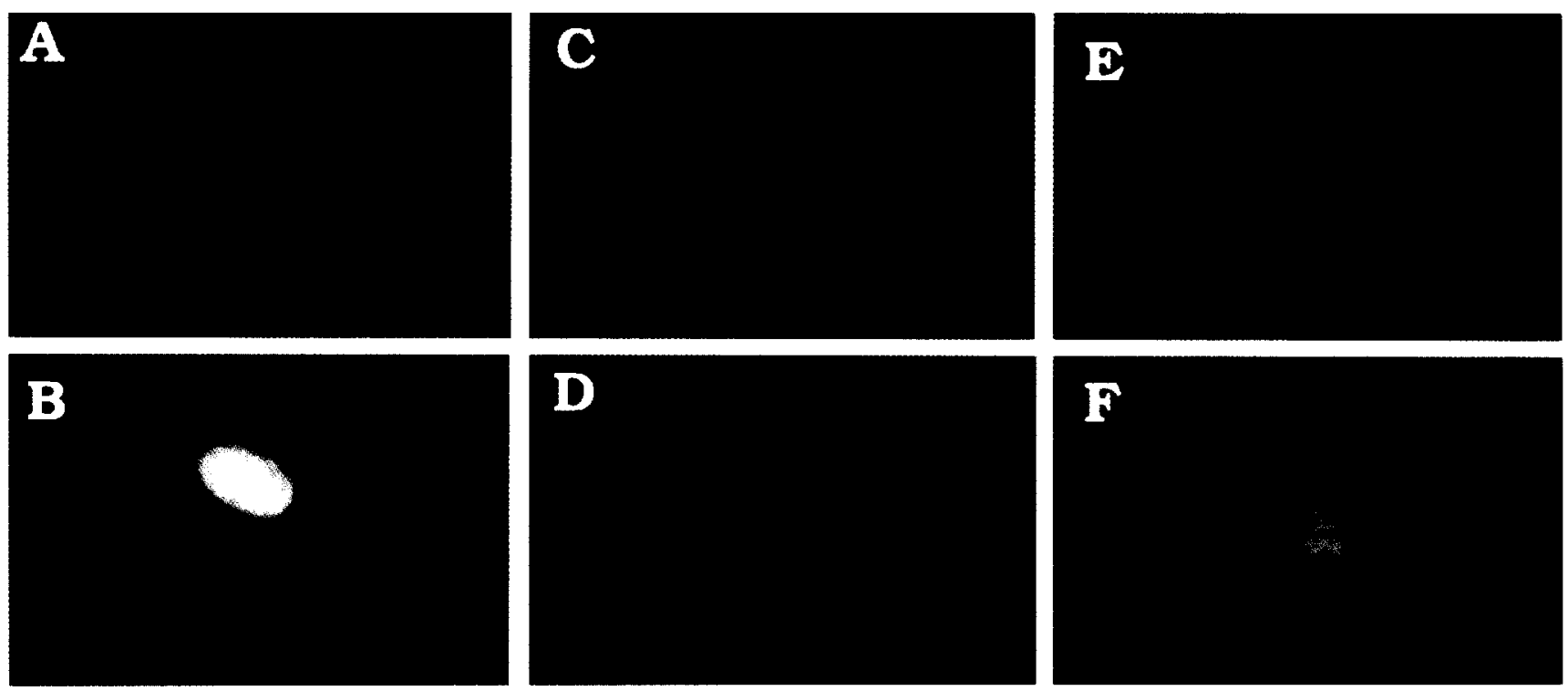

Figure 3. Vectorisation d'ARN par le vecteur MPG dans des fibroblastes humain.

Le complexe ARN/MPG est préformé comme définie dans Matériel et méthodes, et la localisation cellulaire de l'ARN fluorescent est suivie par microscopie optique à fluorescence. $\boldsymbol{A}$ : Contrôle négatif, en absence de MPG aucune transfection d'ARN est observée. $\boldsymbol{C}$ et $\boldsymbol{E}$ : Transfection d'ARN en présence MPG après respectivement 1 et 2 h d'incubation directement sur les cellules en culture. $\boldsymbol{B}, \boldsymbol{D}$ et $\boldsymbol{F}:$ Localisation des noyaux par marquage avec le Hoechst 33258. 


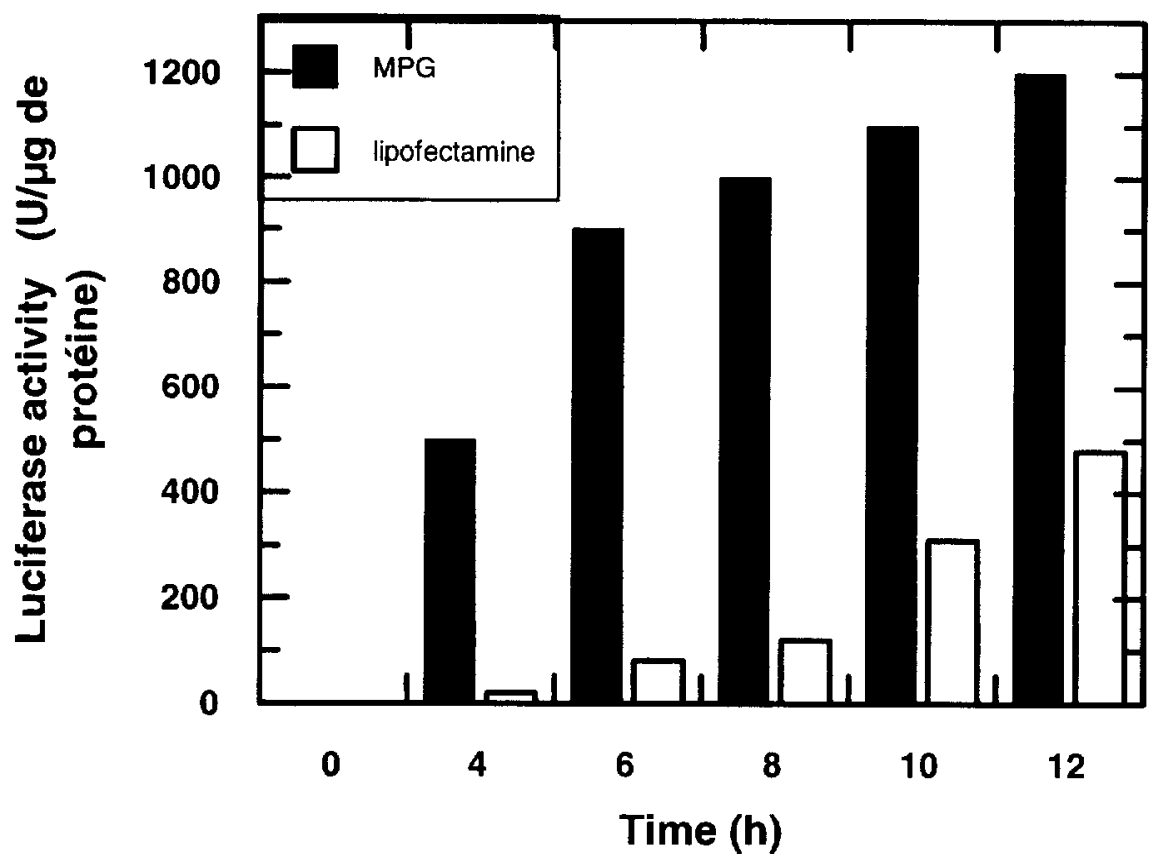

Figure 4. Cinétique d'expression d'un ARNm transfecté par MPG.

L'ARNm $\left(110^{-10} \mathrm{M}\right)$ codant pour la luciférase de Renilla reniformis est préalablement associé avec le vecteur $M P G$, le complexe est ensuite incubé pendant 1 h sur des fibroblastes (HS-68) dans un milieu de culture contenant $10 \%$ de sérum. En cuntrole, l'ARN est transfecté par la lipofectamineTM pendant $5 \mathrm{~h}$ en absence de sérum. L'activité luciférase est mesurée après 4, 6, 8 et 12 h de culture et exprimée en unité arbitraire par $\mu g$ de protéines.

pleinement exprimé dans les cellules et que son implication dans un complexe avec plusieurs peptides ne perturbe pas sa traduction.

\section{Conclusion}

Dans ce travail, nous avons élaboré un peptide vecteur (MPG) extrêmement efficace pour le transfert d'acides nucléiques dans des cellules en culture selon un mécanisme non covalent mettant en jeu des interactions électrostatiques et hydrophobes.

La séquence de ce vecteur « G-A-L-F-L-G-F-L-G-A-A-GS-T-M-G-A-W-S-A-P-K-S-K-R-K-V-Cya » associe un peptide de fusion dérivant de la protéine gp41 de VIH $[26,27]$ avec une séquence de localisation nucléaire issue de l'antigène $T$ du SV40 $[28,29]$. Ce peptide diffuse rapidement vers le cytoplasme $(<1 \mathrm{~min})$ et présente une localisation majoritairement nucléaire après $3 \mathrm{~min}$. MPC, interagit avec les acides nucléiques avec une forte affinité l'ordre de $0,210^{-7} \mathrm{M}$. La formation de complexes MPG/ARN se fait principalement par des interactions électrostatiques impliquants les résidus basiques du peptide et les groupements phosphates de l'acide nucléique. Dans ce cas, le rôle de la séquence de localisation nucléaire serait de favoriser l'interaction avec l'ARNm et non le routage vers le noyaux. Au contraire, cette séquence est essentielle pour le routage du peptide libre vers le noyau. Les interactions électrostatiques ne peuvent pas à elles seules expliquer la totalité du mécanisme de transfection induit par le vecteur MPG. L'association de MPG avec I'ARN engendre des interactions secondaires peptide/peptide, suggérant la présence d'une enveloppe de plusieurs couches de peptide autour de l'acide nucléique, masquant ainsi les propriétés de l'ARN. La particule ainsi for- mée présenterait donc principalement les propriétés du peptide, facilitant ainsi sa pénétration dans les cellules. En particulier, le domaine peptide de fusion de MPG jouerait un rôle clé dans le transfert rapide de I'ARN à travers la membrane plasmique vers le cytoplasme. En revanche, la présence de cette enveloppe peptidique ne perturbe en aucun cas la traduction de I'ARNm dans la cellule, qui serait donc rapidement libéré dans le cytoplasme, comme le dérnontre l'expression rapide d'un ARNm codant pour la luciférase après transfection avec MPG

En conséquence le vecteur MPG constitue un excellent outil pour la vectorisation d'acides nucléiques. L'utilisation de ce nouveau système pour l'internalisation de gène présente de nombreux avantages par rapport aux techniques couramment utilisées $[3,4,6,7,10]$. La formation du complexe est rapide et non covalente ce qui facilite la libération de l'acide nucléique dans la cellule, essentielle pour la traduction de l'ARNm en protéines. MPG transfert les acides nucléiques dans le cyloplasme en moins de 1 h au lieu de 4-5 h lors de l'utilisation des lipides cationiques, avec rendement de transfection de $90 \%$ qui est 2 fois supérieur à celui obtenue avec la lipofectamine. De plus, le vecteur MPG ne présente pas de toxicité pour les cellules jusqu'à des concentrations de l'ordre de $10^{-3} \mathrm{M}$, qui sont largement supérieures aux concentrations requises pour le transfert d'ARN $\left(10^{-6} \mathrm{M}\right)$ et contrairement aux lipides cationiques, MPG est insensible à la présence de $10 \%$ de sérum dans le milieu de culture $[5,6,8]$.

En conclusion, le peptide MPG constitue un outil puissant pour le transfert de gène. Le développement de cette nouvelle stratégie devrait généraliser son utilisation en tant qu'outil de laboratoire pour l'étude de cellules en cultures mais aussi à plus long terme fournir de nouveau outils pour la thérapie génique. 


\section{ABRIDGED VERSION}

A major problem for the development of gene or antisense therapy is the low permeability of the cell membrane for nucleic acids. The development of antisense therapy technology has focused in part on the design of new methods for gene delivery into cells [1-3]. Many approaches, including cationic liposome transfection, mediated by cytofectin ${ }^{\mathrm{TM}}$ or lipofec$\operatorname{tin}^{\mathrm{TM}}$ [5-7] and polymeric DNA-binding cations, such as poly-L-lysine $[8,9]$ or polyethylenimine $[10,11]$, are commonly used for antisense and oligonucleotide delivery in vitro and in vivo. Despite much use, these approaches to gene and plasmid transfection remain less effective than the more hazardous viral vectors [3]. In the present work we describe a new efficient and non-hazardous strategy for the delivery of nucleic acids into mammalian cells using a short peptide vector. The peptide vector, MPG, was designed and synthesized according to well-defined criteria and its ability to both interact with, and transfer an mRNA $(1.4 \mathrm{kB})$ encoding the p 66 subunit of the HIV-1 reverse transcriptase (RT) [17] was evaluated in non-transformed human fibroblasts (HS-68). MPG exhibits a relatively high affinity for RNA molecules and is able to deliver them into non-transformed human fibroblats (HS 68). The interaction of the mRNA with the MPG does not alter the RNA traduction after transfection as revealed by a reporter gene encoding the Renilla luciferase.

$M P G-1$ contains 27 residues with the following sequence ' $G$ A-L-F-L-G-F-L-G-A-A-G-S-I-M-G-A-W-S-Q-P-K-S-K-K$\mathrm{K}-\mathrm{V}$-Cya' with a cysteamide group at the C-terminus [15, 16]. MPG contains two independent domains (a) an hydrophilic sequence ' $K-S-K-R-K-V$ ', containing a nuclear localization signal (NLS) of the SV40 large $T$ antigen $[25,26]$ and (b) an hydrophobic sequence 'G-A-L-F-L-G-F-L-G-AA-G-S-T-M-G-A', which is derived from the fusion sequence of the viral protein gp $41[23,24]$. In order to monitor the free peptide in the cell, a Iucifer yellow was covalently attached using the cysteamide group at the C-terminus. MPG localizes rapidly to the cytoplasm of human fibroblasts (less that $1 \mathrm{~min}$ ) and then presents a predominantly nuclear localization in less than $3 \mathrm{~min}$.

This peptide vector, MPG, contains a single Trp 18 residue located, between the fusion and the nuclear localization sequence motifs. This $\operatorname{Trp}$ residue constitutes a very sensitive probe to monitor and quantify the interaction of MPG with various nucleic acids. The binding of single stranded mRNA encoding the p 66 subunit of HIV-1 RT induces a marked quenching of the intrinsic fluorescence of MPG with a saturating value of $23 \%$, whatever the mRNA used (fluorescently labelled or not), without modifying the maximum of fluorescence emission centered at $340 \mathrm{~nm}$. MPG presents a relatively high affinity for both unlabelled and fluorescein labelled mRNA with a similar apparent dissociation constant in the range $1.10^{-7} \mathrm{M}$, showing that the fluorescent groups attached to the oligonucleotide do not interfere with its binding to MPG, and thus validating the use of such fluorescent probes for further cellular investigations. In both case, the saturation of MPG occurred with a 4000 -fold lower concentration of mRNA, which is at least 13-fold higher than the value calculated on the basis of electrostatic interactions involving the basic residues of MPG (3 Lys and $1 \mathrm{Arg}$ ) and the phosphate groups of mRNA. These results suggest that the mechanism of MPG/RNA complex formation might involve first peptide/RNA interactions, which would then promote peptide/peptide interactions, since no self association of MPG was observed in the absence of RNA.

We have evaluated the ability of MPG to transfer a single stranded fluorescently labelled mRNA into human fibroblastes (HS-68). This new concept of gene delivery was compared to that based on the commonly used cationic lipid : lipofectamin TM [5-7]. Fluorescently labelled mRNA was complexed with MPG and the preformed MPG/mRNA complex was overlaid onto cultured cells and tested for its ability to mediate mRNA delivery into HS 68 fibroblasts. The simple contact of the MPG-nucleic acid complex in solution with mammalian cells in culture was sufficient for MPG to deliver the nucleic acid into the cells in less than $1 \mathrm{~h}$. The efficiency of tranfer was calculated to be higher that 80 $\%$ and no fluorescent staining was visible in cells incubated with mRNA alone, suggesting that uncomplexed mRNA is not able to cross the cell membrane.

Two of the main problems with delivery of mRNA into cultured cells are their high sensitivity to nucleases and their low stability in cell culture media. I Iere we have shown that the complexation with MPG strongly protects mRNA from nucleases and therefore increases the percentage of transfected molecules. Moreover, after transfection with MPG, the mRNA is rapidly expressed in the cell. The kinetics of mRNA expression was monitored by using mRNA encoding a reporter protein, the Renilla luciferase, and the maximal expression occurs $6 \mathrm{~h}$ after transfection with MPG. The high efficiency of MPG is not dependent on the culture media as is the case for most of the lipofection reagents [5, 6]. Finally, MPG is devoid of cytotoxicity at the concentration used for optimal mRNA delivery.

The MPG-based strategy that we have developed overcomes the limitations and hazards that arise in most of the commonly-used methods for gene delivery into mammalian cells. We have indeed succeeded in optimizing a highly efficient system that exhibits no cytotoxicity whatsoever, which bypasses sensitivity to serum, and which reduces time-dependency encountered in transfection techniques considerably. In conclusion, this peptide vector, MPG, constitutes an extremely powerful tool for research and could have an impact both in antisense technology and gene therapy.

Remerciements : Ce travail a été réalisé avec le support du GDR 1153 "Peptides et protéines amphipathiques ", du CNRS, de la FRM (Sidaction), de l'Arc et du GDR peptide. PV et LC sont respectivement financés par Sandoz-CNRS et une bourse de l'ANRS. Nous tenons à remercier le $D^{r} R$. Bennes pour sa participation à l'élaboration du vecteur et pour l'incitation aux expériences d'interactions non covalentes, le $\mathrm{P}^{\mathrm{r}} \mathrm{R}$. Goody pour nous avoir fournic lo clone originale de la reverse transcriptase de $\mathrm{VIH}-1$ et le $D^{\prime} \mathrm{J}$. Mery pour la synthèse des peptides. 


\section{RÉFÉRENCES}

1. Wagner R.W. 1994. Gene inhibition using antisense oligonucleotides. Nature 372, 333-335

2. Agrawal S. 1996. Antisense oligonucleotides: toward clinical trials. TIBTECH 14, 376-387

3. Harris J.D., Lemoine NR, 1996. Strategies for targeted gene therapy. TIG 12, 400-405

4. Behr J.-P., Demeneix B., Loeffler J.-P., Perez-Mutul J. 1989. Efficient gene transfer into mammalian primary endocrine cells with lipopolyamine-coated DNA. Proc. Nath. Acad. Sci. USA 86, 69826986

5. Flegner P.L., Gadek T.R., Hom M., Roman R., Chan H.W., Wenz M., Northrop J.P., Ringold M.G., Danielsen M. 1987, Lipofection: A highly efficient lipid-mediated DNA-transfection procedure. Proc. Natl. Acad. Sci. USA 84, 7413-7417

6. Felgner J.H., Kumar R., Sridhar C.N., Wheeler C.J., Tsai Y.J., Border R., Ramsey P., Martin M., Felgber P.L. 1994. Enhanced gene delivery and mechanism studies with a novel series of cationic lipid formulation. J. Biol. Chem. $269: 2550-2561$

7. Lewis G.J., Lin K., Kothavale A., Flanagan W.M., Matteucci M.D. Deprince R.B., Mook R.A., Hendren R.W., Wagner R.W. 1996. A serum resistant cytofectin for cellular delivery of antisense oligonucleotides and plasmid DNA. Proc. Notl. Acad. Sci. USA 93, 3176-3181

8. Michael S.J., Curie, D.T. 1994. Strategies to achieve targeted gene delivery via the receptor medlated endocytosis pathway. Gene Therapy 1, 223-232

9. Bordier B., Perala-Heape M., Degols G., Lebleu B., Litvak S. Sarih-Cottin L., Helene C. 1995. Sequence specific inhibition of human immunodeficiency virus (HIV) reverse transcriptase by antisense oligonucleotides: Comparative study in cell-free assays and in HIV-infected cells. Proc. Natl. Acad. Sci. 92, 9383-9387

10. Behr J-P. 1994. Gene transfer with synthetic cationic amphiphiles: prospects for gene therapy. Bioconjugate Chem. 5, 382389

11. Boussif $O$, Lezoualch F.. Zanta M-A., Mergny M.D. Scherman D. Demeneix B., Behr J.P. 1995 A versatile vector for gene and oligonucleotide transfer into cells in culture and in vivo: Polyethylenimine. Proc. Natt. Acad. Sci. USA 92, 7297-7301

12. Vitiello L., Chonn A., Wasserman D.J., Duff C., Worton R.G. 1996. Condensation of plasmid DNA with polylysine improves liposome-mediated gene transfer into established and primary muscle cells. Gene Therapy 3, 396-404

13. Gottschalk S., Sparrow J.T., Haver J., Mims M.P., Leland F.E. Woo S. L.C., Smith L.C. 1996. A novel DNA-peptide complex for efficlent gene transfer and expression in mammalian cells. Gerie Therapy 3, 448-457

14. Divita G., Baillon G., Rittinger K., Chermann J-C., Goody R.S. 1995. Interface peptides as structure-based human immunodefi- clency virus reverse transcriptase inhibitors. J. Biol. Chem. 270 , 28042-28646

15. Mery J., Granier C., Juin M., Brugidou J. 1993. Disulfide linkage to polyacrylic resin for automated Fmoc peptide synthesis. Immunochemical applications of peptide resins and mercaptoamide peptides. Int. J. Peptide Protien Res. 42 : 44-52

16. Vidal P., Chaloin L., Méry J., Lamb N., Lautredou N., Bennes R., Heitz F. 1996. Solid-phase synthesis and cellular localization of a Cand/ or N-terminal labelled peptide. J. Pep. Sci. 2, 125-133

17. Müller B., Restle T., Weiss S., Gautel M., Sczakiel G., Goody R.S. 1989. Co-expression of the subunits of the heterodimer of HIV-1 reverse transcriptase in Escherichia coli. J. Biol. Chem. 264, 1397513978

18. Matthews J.C.. Hori K., Cormier M.J. 1987. Purification and properties of reilla reniformis luciferase. Biochemistry 16, 85-91

19. Sherf B.A., Navarro S.L., Hannah R.R., Wood K.V. 1996. Dual-Luclferase reporter assay: an advanced co-reporter technology integrating firefly and renilla luciferase assays. Promega Notes 57 , 2-9

20. Sambrook J., Fritsch E.P., Maniatis T. 1989. Molecular Cloning. Cold Spring Harbor Laboratory Press

21. Morris M.C., Divita G., communication personnelle

22. Divita G., Rittinger K., Geourjon C., Deleage G., Goody R.S. 1995. Dimerization kinetics of HIV-1 and HIV-2 reverse transcriptase: A two step process. J. Mol. Biol. 245, 508-521

23. Müller B., Restle T., Reinstein J., Goody R.S. 1991. Interaction of fluorescently labelled dideoxynucleotldes with HIV-1 reverse transcriptase. Biochemistry 30, 3709-3715

24. Girard F., Fernander A. Lamb N. 1995. Delayed cyclin A and B1 degradation in non-transformed mammalian cells. J. Cell. Sci. $108,2599-2608$

25. Girard F., Strausfeld U., Fernandez A., Lamb, N. 1991. Cyclin A is required for the onset of DNA replication in mammalian fibroblasts. Cell 67, 1169-1179.

26. Gallaher W.R., 1987. Detection of a fusion sequence in the transmembrane protein of human immunodeficiency virus. Cell $50,327-328$

27. Freed E.O., Myers D.J., Risser R. 1990. Characterization of the fusion domain of the human immunodeficiency virus type 1 envelope glycoprotein gp41. Proc. Natl. Acad. Sci. USA 87, 46504654

28. Kalderon D., Richardson W.D., Markham A.F., Smith A.E. 1984. Sequence requieremnts for nuclear location of simianvirus 40 large-T antigen. Nature $311,33-38$

29. Dingwall C.. Laskey R. 1992. The nuclear membrane. Science 258, 942-947

30. Burstein E.A., Vedenkina N.S., Ivkova M.N. 1973. Fluorescence and the location of typtophan residues in proteln molecules. Photochem. Photobial. 18, 263-279 